\title{
Remarks on an Enzymatic Amplification System for Use in Point of Care Diagnostics
}

\section{Marcia L Moss*}

BioZyme Inc., Apex, North Carolina, USA

\section{Commentary}

Detection methods to quantify specific protein levels in biological samples for diagnostic purposes typically rely on the use of enzyme linked immunosorbent assays (ELISA) [1,2]. With an ELISA, total protein, rather than the bioactive amount may be quantified, as it is often complexed to naturally occurring aggregates or inhibitors. Thus, in cases where the protein is an enzyme, an activity assay may be more informative and correlative with disease status.

Simple clinical assays detecting active enzyme concentrations are available for a variety of proteins. For example, alanine and aspartate transaminases (ALT and AST) as well as alkaline phosphatase [3-5] levels are used to assess liver function. Elevated quantities of enzymes such as amylase and lipase indicate an inflammatory condition of the pancreas while low levels are predictive of poor function [6,7]. Creatine kinase is released over time during myocardial, and quantification can be obtained with an enzyme or ELISA type assay [8-10].

The enzymatic activity assays typically rely on fluorescent or colorimetric readouts and expensive, specialist equipment. Alkaline phosphatase (AP), for example, uses p-nitrophenylphosphate (pNpp) as a substrate [11]. When the phosphate group is released by AP, the resulting p-nitrophenolate ion generates a yellow product detectable at $405 \mathrm{~nm}$. An assay for lipase also generates p-nitrophenolate by using palmitate-pNpp as a substrate[12]. Lipase and other esterase assays also employ cleavage of a thioester[13]. Hydrolysis of the ester linkage releases a free thiol group that reacts with Ellmans Reagent to produce a yellow color.

The ultimate goal for many of the clinical assays would be to simplify them in order to do point of care diagnostics. There are some simple assays for point of care diagnostics that have been either field tested and/or approved for specific uses that measure total protein. One example is an assay for transaminases that utilizes a paper strip [14]. Researchers field tested a microfluidic device in combination with test strips to determine blood levels of transaminases from individuals with HIV who were known to have liver damage. The test proved to be successful with an approximate accuracy of $84 \%$ when the results were compared to findings from an automated procedure.

Towards the development of a point of care diagnostic assay utilizing an enzyme activity assay, rather than quantifying total protein, an amplification system to measure alkaline phosphatase has been developed $[15,16]$. In this system, the apoenzyme form of sensors such as $\mathrm{D}$ amino acid oxidase (DAO) cannot bind the phosphorylated form of its cofactor flavin adenine di-nucleotide (FAD). Only after dephosphorylation by alkaline phosphatase and reconstitution with the DAO is enzymatic activity restored. Oxidases are enzymes that are commonly used in sensing devices such as those for glucose detection because this technology utilizes electron output for signal detection.

In contrast to metabolic enzyme activity readouts as described above, there are no examples of clinically used proteinase assays although some are in the development stage. The most promising ones to date include measurement of thrombin in a generation assay[17] and determination of bacterial proteinases in wound healing $[18,19]$. In blood clotting, thrombin levels increase with time and is correlative with the ability of the blood sample to clot. Typically, the thrombin generation assay is used with samples from hemophiliacs. For wound healing, Systagenix developed an assay to detect bacterial proteinases. A clinical trial was completed in 2012 and the test is on track to be used diagnostically.

Recently, a colorimetric amplification system for proteinases was described [20] although it could easily be adapted to other enzyme activity assays. The amplification system directly attaches a reporter enzyme, such as horse radish peroxidase, to the substrate. Once the product is generated, a separation system is used to separate the unreacted substrate from the product. The amount of product formed is then quantified by adding substrates for the horse radish peroxidase.

This amplification system is versatile, in that any reporter enzyme and any substrate can be used. However, there are limitations in that the reporter enzyme cannot interfere with the ability of the substrate to be converted to product. In addition, unreacted substrate has to be physically separated from the product. This would make assays such as those described for phosphatases, kinases, lipases, and esterases, for example, to be easily adapted to the colorimetric amplification system. For paper strip and dipstick tests, physical separation of substrate and product is not an issue as the substrate would be directly attached to a solid support. One could envision a simple test.whereby a paper strip could be incubated with a biological fluid, the paper strip removed, and then substrates for the reporter enzyme added to the fluid in order to generate a colored product. Alternatively, for a dipstick test, the fluid could be allowed to travel through the stick, such as with a urine pregnancy test, bringing with it, the product that contains the reporter enzyme. Then on a separate channel on the stick, the product could come into contact with an immobilized substrate for the reporter enzyme (Figure 1).

In cases where a color readout is not applicable, this technique could be adapted to a voltage, fluorimetric, or chemilumiscent readout. For a voltage readout, the enzyme could be an oxidase and utilized in a similar fashion to what has already been done for glucose sensors for diabetic patients. If a fluorescence or chemilumiscence readout is required, the substrates for the reporter enzyme can be changed. Thus, this amplification system is adaptable to a variety of situations, depending on the enzyme activity that needs to be quantified, and

*Corresponding author: Marcia L Moss, BioZyme Inc., Apex, North Carolina, USA; E-mail: Moss0610@yahoo.com

Received: July 16, 2015; Accepted: August 10, 2015; Published August 12, 2015

Citation: Moss ML (2015) Remarks on an Enzymatic Amplification System for Use in Point of Care Diagnostics. Biochem Anal Biochem 4: 203. doi:10.4172/21611009.1000203

Copyright: (C) 2015 Moss ML. This is an open-access article distributed under the terms of the Creative Commons Attribution License, which permits unrestricted use, distribution, and reproduction in any medium, provided the original author and source are credited. 
Citation: Moss ML (2015) Remarks on an Enzymatic Amplification System for Use in Point of Care Diagnostics. Biochem Anal Biochem 4: 203. doi:10.4172/2161-1009.1000203

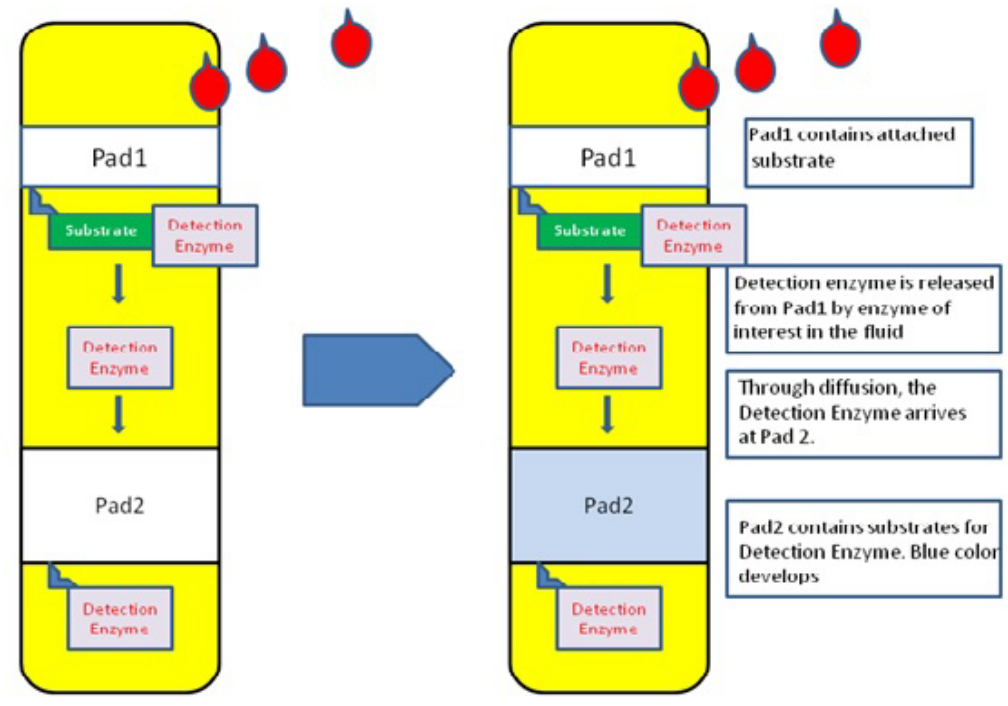

Figure 1: Dip stick test using enzymatic amplification system.

whether or not point of care diagnostics or a laboratory setting is being used.

\section{References}

1. Cole LA1 (2012) The hCG assay or pregnancy test. Clin Chem Lab Med 50 : 617-630.

2. Arora DR, Maheshwari M, Arora B (2013) Rapid Point-of-Care Testing for Detection of HIV and Clinical Monitoring. ISRN AIDS 2013: 287269

3. Pollock NR, McGray S, Colby DJ, Noubary F, Nguyen H, et al. (2013) Field evaluation of a prototype paper-based point-of-care fingerstick transaminase test.

4. Pollock NR, Rolland JP, Kumar S, Beattie PD, Jain S, et al. (2012) A paperbased multiplexed transaminase test for low-cost, point-of-care liver function testing, Science translational medicine 4: 152.

5. Wieme RJ, Demeulenaere L (1970) Enzyme assays in liver disease. J Clin Pathol Suppl (Assoc Clin Pathol) 4: 51-59.

6. Pezzilli R, Ventrucci M, Talarico R, Naldoni P, Cassano A, et al. (1989) [Serum pancreatic enzymes in the diagnosis of carcinoma of the pancreas]. $G$ Ital Oncol 9: 7-13.

7. Ventrucci M, Pezzilli R, Gullo L, Platé L, Sprovieri G, et al. (1989) Role of serum pancreatic enzyme assays in diagnosis of pancreatic disease. Dig Dis Sci 34: $39-45$.

8. Bruins Slot MH, van der Heijden GJ, Stelpstra SD, Hoes AW, Rutten FH (2013) Point-of-care tests in suspected acute myocardial infarction: a systematic review. Int J Cardiol 168: 5355-5362.

9. Rapaport E (1977) Serum enzymes and isoenzymes in the diagnosis of acute myocardial infarction. Part II: Isoenzymes. Mod Concepts Cardiovasc Dis 46: $47-50$.

10. Rapaport E (1977) Serum enzymes and isoenzymes in the diagnosis of acute myocardial infarction. Part I: serum enzymes. Mod Concepts Cardiovasc Dis 46: $43-46$
11. Bessey OA, Lowry OH, Brock MJ (1946) A method for the rapid determination of alkaline phosphates with five cubic millimeters of serum. J Biol Chem 164 321-329.

12. Pencreac'h G, Leullier M, Baratti JC (1997) Properties of free and immobilized lipase from Pseudomonas cepacia. Biotechnol Bioeng 56: 181-189.

13. Choi SJ, Hwang JM, Kim SI (2003) A colorimetric microplate assay method for high throughput analysis of lipase activity. J Biochem Mol Biol 36: 417-420.

14. Pollock NR, Colby D, Rolland JP (2013) A point-of-care paper-based fingerstick transaminase test: Toward low-cost "lab-on-a-chip" technology for the developing world, Clinical gastroenterology and hepatology : the official clinical practice journal of the American Gastroenterological Association 11: 478-482.

15. Obzansky DM, Rabin BR, Simons DM, Tseng SY, Severino DM, et al. (1991) Sensitive, colorimetric enzyme amplification cascade for determination of alkaline phosphatase and application of the method to an immunoassay of thyrotropin. Clinical chemistry 37: 1513-1518.

16. Harbron S, Eggelte HJ, Rabin BR (1991) Amplified colorimetric assay of alkaline phosphatase using riboflavin 4'-phosphate: A simple method for measuring riboflavin and riboflavin 5'-phosphate. Analytical biochemistry 198: 47-51.

17. Brooks MB and Catalfamo JL (2013) Current diagnostic trends in coagulation disorders among dogs and cats, The Veterinary clinics of North America. Small animal practice 43 6: 1349-137

18. Moor AN, Vachon DJ, Gould LJ (2009) Proteolytic activity in wound fluids and tissues derived from chronic venous leg ulcers, Wound repair and regeneration : official publication of the Wound Healing Society [and] the European Tissue Repair Society 17: 832-839.

19. Liu Y, Min D, Bolton T, Nube V, Twigg SM, et al. (2009) Increased matrix metalloproteinase- 9 predicts poor wound healing in diabetic foot ulcers, Diabetes care 32: 117-119.

20. Moss ML, Koller G, Bartsch JW, Rakow S, Schlomann U, et al. (2015) A colorimetric-based amplification system for proteinases including MMP2 and ADAM8. Anal Biochem 484: 75-81. 